by the other race, altho these two races show no structural differences. By isolating fruit with limb cages and making use of artificial infestation we hope to get some interesting lights on this problem. It is of immediate practical value because it means danger or no danger from infested wayside or farmyard trees lying near commercial orchards.

Probably the foregoing will keep us rather well occupied and doubtless other phases will turn up later.

Some of the members of this association have had experience in working out a problem of this type. We should be very glad to receive from these any suggestions as to what to do and what not to do in our work.

Mr. BraUcher: What is the best method of protecting fruit from this insect, and how can you tell whether the fruit is infested? My experience has been that there is not much indication of infestation on the outside of the fruit.

Mr. O'Kane: In the case of certain varieties of apple, it is sometimes difficult to determine whether or not fruit is infested with this insect, although it is always possible to do so by critically examining it with a hand lens.

Prasident Britton: Doctor Felt will now present his paper, entitled "Spraying for the Codling Moth."

\title{
SPRAYING FOR THE CODLING MOTH
}

By E. P. Feur, Albany, N. Y.

The main purpose of our experiments was to test the relative efficiency of a coarse driving spray, such as that produced by a typical Bordeaux nozzle with a pressure of over 100 pounds, in comparison with the fine misty spray of the Vermorel nozzle and its various. modifications.

Comparisons were made between single sprays of each of the above mentioned kinds, applied just after the blossoms fell (plots 1 and 4), between two sprays of each kind, one given just after the blossoms. fell and the second just before the sepals closed (plots 2 and 5), and finally between two such sprays and a third applied with a Friend nozzle the last week in July, for the purpose of destroying the second brood of the codling moth (plots 3 and 6 ).

These experiments were conducted in a young orchard belonging to Mr. W. H. Hart of Arlington, N. Y., near Poughkeepsie, the first. 
being duplicated in the orchard of Edward VanAlstyne at Kinderhook. The Hart orehard is on a moderately high hill, the trees being thrifty, about fifteen years old, 15 to 18 feet high and 30 feet apart. Each plot consisted of approximately forty-two trees, six trees in a row one way and seven in a row the other way, the central six being the actual experimental trees and invariably Baldwins, though some of the barrier trees were Northern Spys. The experimental trees were carefully selected for uniformity of size, fruitage and infestation. An examination of one resulted in finding thirteen empty codling moth cells and of another, none. These were not in the experimental area. The orchard as a whole had not been sprayed much prior to the past season.

The spraying followed the usual practice of orchardists, the aim being to cover the entire tree and especially to hit the tips of the young apples with the spray. The Bordeaux nozzles were set so as to give a maximum of rather coarse spray which would not break up into fine drops till about six feet from the nozzle. The aim of this application was to drive the poison straight down into the tip of every young apple, the nozzle being held about 18 to 24 inches from the fruit so far as possible, and the pressure being maintained at about 150 pounds. This gave a stiff, penetrating spray which repeatedly passed the stamens and collected in the lower cavity, especially in the first application. Despite the above, it was found practically impossible to fill the lower calyx cavity in all cases, especially was this true during the second spraying after the stamen bars had withered a little. An examination showed that the dried tips of these organs were very likely to become entangled and present a most effective barrier to the passage of the spray. In practice it was found much more difficult to cover a tree thoroughly with the Bordeaux type of nozzle than it was with the much broader and more evenly distributed spray coming from the Vermorel nozzle.

The trees were sprayed with $51 / 4$ pounds of Grasselli's arsenate of lead and 10 pounds of copper sulfate to each 150 gallons of spray, enough lime being added to neutralize the copper sulfate as determined by the Ferro-cyanide test. The first application was made May 20, the second May 31 and the third June 28. Two check trees were left in the immediate vicinity of the experimental plots.

Observations upon the growth and development of the fruit were made at intervals during the season, and on September 13 and 14 the dropped apples were collected and carefully sorted. It was then found that there were from 14.91 per cent to 26.67 per cent of wormy fruit under the experimental trees, while the check trees had 73.91 
and $81.02 \mathrm{per}$ cent, respectively, of wormy fruit. The apples were picked October 5 to 7 and the remaining windfalls and all on the trees carefully sorted, and these figures, combined with those obtained earlier in the season, were brought together in the following table.

SUMMARY OF PLOTS

\begin{tabular}{|c|c|c|c|c|c|c|c|}
\hline \multirow{2}{*}{ Plot. } & \multirow{2}{*}{$\begin{array}{l}\text { Total No. } \\
\text { of Frult. }\end{array}$} & \multicolumn{2}{|c|}{ Clean Fruit. } & \multicolumn{4}{|c|}{ Wormy fruit. } \\
\hline & & No. & Per cent. & No. & Per cent. & $\begin{array}{c}\text { Range of per } \\
\text { cent betwben } \\
\text { trees. }\end{array}$ & $\begin{array}{c}\text { Range in } \\
\text { No. be- } \\
\text { tween trees. }\end{array}$ \\
\hline $1 \ldots$ & 30,177 & 29,818 & 98.81 & 959 & 1.19 & $.63-3.16$ & $30-111$ \\
\hline $2 \ldots$ & 10,316 & 10,206 & 98.93 & 110 & 1.07 & $.61-2.66$ & B- 30 \\
\hline s....... & 9,680 & 9,582 & 98.99 & 98 & 1.01 & $.32-2.64$ & $4-29$ \\
\hline $4 \ldots \ldots$ & 20,818 & 20,017 & 98.55 & 296 & 1.45 & $.96-2.64$ & $86-80$ \\
\hline 5. .... & 19,275 & 19,084 & 99.01 & 191 & .99 & $.49-1.51$ & $15-61$ \\
\hline $6 \ldots \ldots$ & $7,7.10$ & 7,683 & 99. & 77 & 1. & $.59-2.74$ & $4-23$ \\
\hline Check. & 8,251 & 2,366 & 72.73 & 885 & 27.27 & $25.71-33.57$ & $217-668$ \\
\hline
\end{tabular}

Bearing in mind that plots 1 to 3 were sprayed with Vermorel nozzles and 4 to 6 with Bordeaux nozzles, as described above, it will be seen that in each of these groups there is a successive decrease in the number of wormy fruit obtained from the various plots. This, while apparently significant, has no bearing upon the problem, since there is a similar decrease in the total number of fruit upon the trees of the various plots. The percentages of clean fruit or the percentages of wormy fruit, it will be seen, are remarkably uniform for each .of the six plots, showing that so far as this orchard is concerned under conditions obtaining the past season, there was very little difference between treatment with a coarse driving spray applied at a relatively high pressure and a finer spray which under no conditions could be driven with much force. Furthermore, it is impossible from a study of the percentages, to find any very marked benefit from the second and third applications unless it be in the case of the treatments with the Bordeaux nozzle. Even then the latter only approzimate and hardly exceed the results obtained with the Vermorel nozzle. As pointed out before, it was found much more difficult to cover a tree thoroughly with the Bordeaux than with the Vermorel nozzle. Reference to the check trees shows a material benefit accruing from even one application, since the sprayed plots gave at least 98.55 per cent of worm free fruit, while the unsprayed or check trees produced but 72.73 per cent of worm free fruit. 
An analysis of the records of individual trees in the various plots summarized in the following table, discloses an interesting condition.

VARIATION IN INDIVIDUAL TREES

\begin{tabular}{|c|c|c|c|c|c|}
\hline \multirow{2}{*}{ Plot. } & \multicolumn{2}{|c|}{ Maximum Tree. } & \multicolumn{2}{|c|}{ Minimum Tree. } & \multirow{2}{*}{$\begin{array}{l}\text { Range in No, of Wormy } \\
\text { Fruit. }\end{array}$} \\
\hline & No. Fruit. & $\begin{array}{l}\text { Per cent } \\
\text { Wormy. }\end{array}$ & No. Fruit. & $\begin{array}{l}\text { Per cent } \\
\text { Wormy. }\end{array}$ & \\
\hline $1, \ldots \ldots \ldots \ldots \ldots \ldots \ldots \ldots$ & 8,745 & .63 & 2,507 & 3.16 & $30-111$ \\
\hline$\cdots$ & 3,649 & .75 & 226 & 2.66 & $6-30$ \\
\hline 3.... & 2,298 & .61 & 417 & 2.64 & $4-29$ \\
\hline 4....................... & 5,044 & .96 & 3,002 & 2.64 & $36-80$ \\
\hline $5, \ldots \ldots \ldots, \ldots, \ldots, \ldots$ & 5,187 & .49 & 994 & 1.50 & $15-61$ \\
\hline 6........................... & 8,821 & .70 & 767 & 2.74 & $4-23$ \\
\hline
\end{tabular}

The maximum tree of a plot invariably produced the lowest or nearly the lowest percentage of wormy fruit, while the reverse was true of the minimum tree. It will be seen that the variation in number of wormy apples on the various trees was not very great, indicating a fairly uniform degree of infestation. Were such to be true we would expect a lower percentage, as shown by the figures for wormy fruit, on the heavily laden trees. A reference to the record of the plots as a whole shows practically no variation in the percentages of wormy fruit between the more and the less productive plots. This may be due in part to the fact that the plots sprayed two and three times yielded less fruit than those receiving one application of poison - the smaller yield offsetting in a measure the benefit derived from the second and third sprayings.

It may be inferred from the above that unusually favoring conditions resulted in this somewhat anomalous showing. The first experiment, that is, a single application with the Bordeaux and the Vermorel nozzles was also tried at Kinderhook under different conditions, since the trees were older and, moreover, were in the vicinity of still older trees. There is every reason for believing that the codling moth was more abundant in this latter orchard than in the first named. Two plots were laid out in the same manner as at Poughkeepsie and thoroughly sprayed. One plot gave an average of 98.96 per cent of worm free fruit and the other of 98.27 , while the check trees produced but 73.08 per cent of worm free fruit. Owing to there being no engine available for these latter experiments and the difficulty of maintaining a suitable pressure by hand, the 
spraying was not as thorough as that at Poughkeepsie. The result is shown in a slight lowering in the percentage of perfect fruit.

A study of the wormy fruit gives some interesting data, since it was found on plots 1 to 3 , that $10 \%$ to $18.36 \%$ of all the wormy apples were entered at the end, an average of $14 \%$ end wormy. Similarly, in the case of plots 4 to 6 , the variation was from $9.94 \%$. to $12.50 \%$ or an average of $11.50 \%$ of end wormy apples in the total infested. Comparing these percentages with the $69.37 \%$ end wormy of the infested apples on the two check trees, it will be seen that the major proportion of the codling moth larvæ destroyed, must have been killed in or about the blossom end because of the enormous reduction in the sprayed fruit of the number of end wormy apples. There is a slight percentage in this respect in favor of the coarse spray with the Bordeaux nozzles. Duplicate experiments in another orchard at Kinderhook gave $17.51 \%$ to $18.9 \%$ end wormy fruit on the sprayed trees, while on the check trees there were $37.28 \%$ end wormy fruit. It is evident from the above that the spraying results in the marked reduction in the percentage of end wormy fruit, and that this benefit is secured in large measure at least, without regard to the amount of poison driven into the lower calyx cavity.

The results given above would seem to justify, so far as the Hudson River is concerned, the belief that one thorough spraying with a Vermorel nozzle within a week or ten days after the blossoms fall, will result in protecting a very large percentage of the fruit from codling moth injury.

MR. RUMSEY: I have a set of photographs with me showing the final results of a test we made at the West Virginia Agricultural Experiment Station to determine the relative merits of a mist spray and a coarse, high pressure spray for the codling moth. Before passing the pictures I will give some details of the experiment. Fifty. three Ben Davis trees were used in the work. Twenty-four trees were sprayed four times with three pounds of arsenate of lead to fifty gallons of Bordeaux, using a "Vermorel" nozzle with a pressure of about one hundred pounds. The same number of trees were sprayed once with one pound of arsenate of lead to fifty gallons of water, using a "Bordeaux" nozzle, connected to the spray rod by an attachment bent at an angle of $45^{\circ}$, with a pressure of two hundred to two hundred and fifty pounds. The spray was applied just after the petals fell. To the trees which received four sprayings the last spray was applied July 21. Five trees of the same variety were reserved 
as checks. Five trees were also selected from each of the different methods of treatment. The fruit from the fifteen trees was examined about every two weeks during the season, beginning with the June drop. A record was made of the wormy apples as to whether the worms entered at the calyx, side or stem of the fruit. While the test was made primarily against the codling moth a record was also kept of the curculio marked apples.

The percentages marked on the photographs are simply those obtained from the picked fruit as seen in the pictures. When we take into consideration the dropped apples from the check trees, the per cent of wormy and curculio marked fruit will be increased as it may also be in the sprayed trees. The average per cent of wormy and curculio marked fruit as seen in the pictures is as follows:

Check trees : per cent wormy, 36 ; per cent curculio marked, 34 .

Mist spray : per cent wormy, 3; per cent curculio marked, 11.

Coarse spray (high pressure): per cent wormy, 2; per cent curculio marked, 11.

Mr. Sanderson: Doctor Felt's results correspond exactly with what I have secured in New Hampshire.

I would like to know what results he got from the use of the Friend nozzle. I wish there was some way of using the word "Vermorel," as applied to the different forms of nozzles, without using the one name. I think we had better refer it to the Committee on Nomenclature, and get a name for the special kinds. It has been suggested that this form of nozzles be called the "Disc" type, which term seems worthy of adoption.

My' experience has been that the Friend is superior to the old nozzle. As regards the driving spray: I do believe that the driving spray is superior in that you can get the spray into the tree, and get the fruit treated, which you cannot do with a mist spray.

Mr. Frut: I have the very highest respect for Professor Sanderson's opinions, but I must take a diametrically opposite position. I must say, from my observations, that you will have great difficulty in covering the trees thoroughly with a driving spray.

Mr. Braucher: The first season that I used the Bordeaux nozzle my experience was the same as Doctor Felt's; I was unable to cover the trees thoroughly when using a single nozzle. By using two nozzles the past season with a $\mathrm{Y}$ and a $45^{\circ}$ crook, having the nozzles set so the two fan-shaped sprays were parallel to each other and to the horizon and at right angle to the extension rod I was able to do very 
satisfactory work. When the nozzles are properly set and the coarse spray is used the fans meet about four or five feet from the nozzles and at 200 pounds pressure give a fine driving spray that can be directed downward into the calyx cups and do very satisfactory work.

SeCRETARY Burgess: I would suggest to the members that after they see the spraying demonstration tomorrow, they try an adaptation of the solid stream spray, as I believe it is the coming system for treating apple orchards.

President Britron: The next paper will be read by Prof. R. A. Cooley, Bozeman, Mont., entitled "Notes on the Ten-Lined Potato Beetle in Montana."

\section{NOTES ON THE TEN-LINED POTATO BEETLE IN MONTANA}

By R. A. Cooler, Montana Agrioultural College

During the summer of 1907 and again in 1908 frequent observations were made on the life history of the ten-lined potato beetle in a small patch of potatoes in the home garden at Bozeman, Montana, and the writer became convinced that only one brood of larve was produced. The principal points in the life history were followed during both seasons, including the first appearance of the adults, the eggs on potato and on closely related wild plants, the development of the lar. $v æ$, their disappearance for pupation and the subsequent appearance of fresh adults. In both seasons the adults disappeared without depositing eggs for a second generation.

It seemed desirable, however, to make cage experiments, and accordingly adults were taken into the insectary on June 19, 1909. Our notes for this season show that the first adult was observed on June 2. On June 7 adults were becoming plentiful and were seen on potatoes in the garden, and on June 13 eggs were being laid plentifully. The beetles taken on June 19 were then clearly of the overwintered brood. These beetles in the cages laid eggs promptly and plentifully. The first eggs hatched in thirteen days and the larvæ went into the earth on July 13. The first adults appeared on July 30 , and after feeding for a few days disappeared into the earth on August 13.

Most of the over-wintered females died after laying a few clusters of eggs, but one individual continued to lay at frequent intervals 